\title{
Evaluation of vigor and tolerance of sweet corn seeds under hypoxia ${ }^{1}$
}

\author{
Jéssica de Lucena Marinho ${ }^{2 *}$ (iD), Denis Santiago da $\operatorname{Costa}^{3}$ (iD), Deived Uilian de \\ Carvalho $^{2}$ (D), Maria Aparecida da Cruz ${ }^{2}$ (D), Claudemir Zucareli²
}

\begin{abstract}
Evaluation of the physiological potential of seeds by fast and efficient methods is an important step in the process of production and commercialization of sweet corn seeds. The aim of this study was to discriminate sweet corn seed lots by applying multivariate methods regarding the usual vigor tests to verify the sensitivity of these seeds to flood conditions and to verify if the submersion test has potential for classifying lots of this species regarding vigor. Five seed lots of sweet corn were tested for moisture content and physiological potential. Cluster analysis and principal component analysis were performed on the data to discriminate the seed lots regarding initial vigor. Subsequently, two of these lots were selected for the water submersion test, performed with four replicates of 150 seeds, which were submerged in $100 \mathrm{~mL}$ of distilled water for $0,24,48,72$, and 96 hours at $25^{\circ} \mathrm{C}$, and they then underwent the germination test. Discrimination of sweet corn seed lots is possible through multivariate analysis. Sweet corn seeds are sensitive to submersion in water; however, the test did not allow seed lots to be differentiated for vigor.
\end{abstract}

Index terms: physiological potential, flooding, germination, Zea mays convar, Saccharata.

\section{Avaliação do vigor e tolerância de lotes de sementes de milho doce a condições de hipóxia}

\begin{abstract}
RESUMO - A avaliação do potencial fisiológico de sementes por métodos rápidos e eficientes constitui-se em etapa importante do processo de produção e comercialização de sementes de milho doce. Nesse sentido, essa pesquisa objetivou-se discriminar lotes de sementes de milho doce por meio da aplicação de métodos multivariados quanto aos testes de vigor usuais, averiguar a sensibilidade dessas sementes a condições de alagamento e verificar se o teste de submersão tem potencial de classificar lotes desta espécie quanto ao vigor. Cinco lotes de sementes de milho doce, foram submetidas aos testes para avaliação do teor de água e potencial fisiológico. Os dados obtidos foram submetidos à análise de agrupamento e componentes principais para a discriminação dos lotes quanto ao vigor inicial. Posteriormente, dois desses lotes foram selecionados para o teste de submersão em água, realizado com quatro repetições de 150 sementes, que foram submersas em $100 \mathrm{~mL}$ de água destilada durante 0,24 , 48, 72 e 96 horas à $25^{\circ} \mathrm{C}$, e em seguida submetidas ao teste de germinação. A discriminação dos lotes de sementes de milho doce é possível por meio da aplicação de análise multivariada. As sementes de milho doce são sensíveis à submersão em água, entretanto, o teste não possibilitou a diferenciação de lotes quanto ao vigor.
\end{abstract}

Termos para indexação: potencial fisiológico, alagamento, germinação, Zea mays convar, Saccharata.

\section{Introduction}

Sweet corn has mutant alleles in its genome that impede conversion of sugars into starch in the endosperm, lending the seeds their sweet taste (Luz et al., 2014). From this characteristic, according to Souza et al. (2013) and Wilson Junior and Mohan (1998), sweet corn seeds (sh-2, for example) have high sucrose content, high free fatty acid content in the

${ }^{1}$ Submitted on $07 / 27 / 2018$. Accepted for publication on 12/06/2018.

${ }^{2}$ Centro de Ciências Agrárias, Universidade Estadual de Londrina, Caixa Postal 10.011, 86.057-970 - Londrina, PR, Brasil. endosperm, and a dysfunctional aleurone layer. This results in sugar imbalance and rupture of the membrane system, and culminates in low seed vigor. In addition, studies suggest that sweet corn genotypes with higher sugar content have a pericarp and membranes that are more fragile and susceptible to damage during the harvest and drying processes (Alvarenga et al., 2013) and, for that reason, special care is necessary for production of high quality seeds.

${ }^{3}$ Instituto Federal de Mato Grosso do Sul, Caixa Postal 287, 79750-000 Nova Andradina, MS, Brasil.

*Corresponding author $<$ jlmarinho@live.com $>$ 
In this context, evaluation of seed germination and vigor by rapid and efficient methods constitutes an important step in the process of production and commercialization of sweet corn seeds because these factors significantly affect establishment of plants and crop yield.

The physiological quality of a seed lot is not easily measureable since only one individual evaluation is not sufficient to define the vigor of the lot. This property is defined by a set of tests; however, discrimination of lots in regard to vigor by means of combined observation of the data of all the tests is complex and time-consuming (Lorentz and Nunes, 2013).

In this respect, the application of multivariate methods for evaluation and classification of seeds lots regarding physiological quality through cluster analysis and principal component analysis may be an efficient alternative.

Cluster analysis explores similarities among individuals, joining all types of sampling units that show similarities in clusters, thus establishing homogeneity within the group and heterogeneity among groups. Principal component analysis, for its part, aims to condense the information contained in various variables, explaining the variation with a reduced number of variables (principal components). This is because the variables that contribute little to variation are eliminated (Fortes et al., 2008).

Although statistics have overwhelming importance for analysis of the variables, obtaining reliable data that translate the physiological quality of the lots by means of effective vigor tests is essential since some methods indicated for evaluation of seed vigor, such as tests based on seedling development, might not be effective for detecting small differences in vigor among the genotypes, as in sweet corn or super sweet corn, or among lots of the same genotype (Zhao et al., 2007). In addition, these tests are considered less sensitive for identification of less vigorous seeds in comparison to the tests that evaluate tolerance to stresses (Alvarenga et al., 2013).

In this context, the water submersion test would be a viable alternative for evaluation of the vigor of sweet corn or super sweet corn seeds because it is considered a test that evaluates tolerance to stress by restricting a factor important for germination, which is oxygen (Tang et al., 2014), and by providing for rapid entry of water in the seeds in the first hours of imbibition, classified as a critical phase of hydration.

Seed response varies according to different degrees of imbibition, arising from the period of submersion. Germination, membrane rupture (in the case of sweet corn), and even seed death may occur (Costa et al., 2008) because the adverse condition of flooding favors loss of viability and vigor (Grzybowski et al., 2015) through causing an initial situation of hypoxia during the first physiological phases of the seeds.
According to Custódio et al. (2009), seed tolerance to flooding varies according to the genotype and especially according to seed vigor. The most vigorous seeds are more tolerant to oxygen deficiency and to the presence of pathogens favored by high moisture (Dantas et al., 2000).

Given this situation, the aims of this study were to discriminate sweet corn seeds lots through application of multivariate methods regarding the usual vigor tests, discovering the sensitivity of these seeds to flooding conditions and checking if the submersion test is able to classify seed lots of this species regarding vigor.

\section{Materials and Methods}

Sweet corn seeds of the hybrid Tropical Plus, represented by five seed lots, were obtained from the Syngenta company. It is a single hybrid, super sweet (brittle gene), and has the characteristics of mean plant size of $2.35 \mathrm{~m}$ and 90 to 110 day cycle (1300 heat units). In addition, it is moderately tolerant to the main diseases that affect this crop. The seeds obtained were treated with insecticides (50\% pirimiphos-methyl 0.016 $\mathrm{L}$. ton $^{-1}$ and $2.5 \%$ Deltamethrin $0.04 \mathrm{~L}$.ton ${ }^{-1}$ ) and fungicides

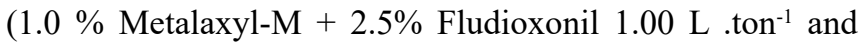
$20 \%$ Carboxin $+20 \%$ Thiram $6.0 \mathrm{~L} \cdot$ ton $^{-1}$ ).

Initially the seeds of each lot underwent testing for evaluation of moisture content and physiological potential through the following evaluations:

Moisture content: determined using two replications of $4.5 \mathrm{~g}$, dried in a laboratory oven regulated to $105^{\circ} \mathrm{C} \pm 3{ }^{\circ} \mathrm{C}$ for 24 hours according to the Rules for Seed Testing (Brasil, 2009).

Germination: determined from eight replications of 50 seeds, which were distributed on "germitest" paper toweling moistened with distilled water in the amount of 2.5 times the weight of the dry paper. The rolls of paper were placed in plastic bags and kept in a Mangelsdorf type germinator in a vertical position, previously regulated to $25^{\circ} \mathrm{C}$. The number of normal seedlings was counted seven days after setting up the test according to the descriptions contained in the Rules for Seed Testing (Brasil, 2009), and the results were expressed in percentage.

Cold test: conducted using the paper roll method with four replications of 50 seeds. The rolls remained at $10{ }^{\circ} \mathrm{C}$ for seven days, as described by Cícero and Vieira (1994). After that, they were transferred to a Mangelsdorf germination chamber at $30^{\circ} \mathrm{C}$ for four more days for counting of normal seedlings.

Accelerated aging: conducted as adapted from the method recommended by the AOSA (2009) in which four replications of 60 seeds were distributed in a single layer over a metallic screen tray fixed within a plastic box containing $40 \mathrm{~mL}$ of distilled water. Lids were placed on the boxes and they were 
kept at $42{ }^{\circ} \mathrm{C}$ for 72 hours. After this period, four replications of 50 seeds were placed to germinate according to the method described for the germination test (Brasil, 2009). Evaluation was made four days after the test was set up, computing the percentage of normal seedlings.

Dry matter of normal seedlings: after counting and evaluation of normal seedlings in the germination test, they were placed in paper bags and then placed in a laboratory oven at $60^{\circ} \mathrm{C} \pm 5^{\circ} \mathrm{C}$ for 72 hours (period in which the samples arrived at constant weight). The seedlings were weighed on a precision balance with $0.001 \mathrm{~g}$ resolution to obtain dry matter (Nakagawa, 1999).

After that, multivariate cluster analysis and principal component analysis were used to analyze the data for discrimination of seeds from each lot in regard to initial vigor. To do so, the mean values of the results of germination, cold test, accelerated aging, and seedling dry matter from each lot were calculated and standardized to zero mean and unit variance to avoid overestimation of each variable in the final result of ANOVA. Cluster analysis was carried out through calculation of the Euclidean distance of each lot, and clustering of similar lots was performed through the Unweighted Pair Group Method using Arithmetic averages (UPGMA) with results expressed in a dendrogram. Principal component analysis was calculated through the $\mathrm{n} \times \mathrm{p}$ matrix, where " $n$ " was the number of lots $(n=5)$ and " $p$ " the number of evaluations: germination, cold test, accelerated aging, and seedling dry matter $(p=4)$. From the correlation matrix, the eigenvalues and eigenvectors were calculated, and the result was visually expressed on a biplot display.

Classification of lots in regard to vigor was performed through a combination of the results of clustering and principal components, and one seed lot that represented vigorous seeds, another average vigor seeds, and another non-vigorous seeds were selected and tested for emergence in a greenhouse for confirmation of the classification. Emergence was tested with four replications of 50 seeds for each lot, which were sown in boxes of sand at a depth of $5 \mathrm{~cm}$. Fourteen days after sowing, the number of emerged seedlings was counted, and the result was expressed in percentage.

After classification and confirmation of the physiological potential of sweet corn seeds, the lot of vigorous seeds was contrasted with that of non-vigorous seeds through submersion in distilled water to verify sensitivity to flooding and if it is possible to discriminate lots with recognizably distinct physiological potential. To do so, the experiment was conducted in a completely randomized design in a $2 \times$ 5 factorial arrangement, representing two seed lots of sweet corn (lot with vigorous seeds and lot with non-vigorous seeds) and five periods of submersion ( $0,24,48,72$, and 96 hours).

Submersion was performed according to Grzybowski et al. (2015), in which four replications of 150 seeds per lot were submerged in $100 \mathrm{~mL}$ of distilled water for the periods of $0,24,48,72$, and 96 hours at $25^{\circ} \mathrm{C}$, and then tested for germination, as described above. The percentage of primary root emergence and the percentage of normal seedlings obtained in the germination test (seven days after sowing) were evaluated. Parallel to the germination test, after each period of flooding, the moisture content of the seeds was determined for each treatment for characterization of the samples after the test.

Analysis of variance was performed on the data obtained and the times adjusted to the first order and second order polynomials, and the seed lots were compared by the Tukey test at $5 \%$ probability, if significant. The software STATISTICA 7 and SAS 9.2 University Edition ${ }^{\circledR}$ was used for these analyses.

\section{Results and Discussion}

The results showed that the lots evaluated had germination greater than $60 \%$, and were in conformity with the standard established by Instrução Normativa (Normative Instruction) No. 45 (Brasil, 2013). Among the lots studied, Euclidean distances ranging from 1.8 to 4.1 were observed (Table 1). These results indicated high similarity for the lots L- 01 and L- 02 , as well as between the lots L- 03 and L- 05 , due to the lower distance values observed. Greater distance was observed for L-04, showing its dissimilarity to the other lots (Figure 1).

Table 1. Characterization of the seed lots of sweet corn, Tropical Plus hybrid, in regard to germination, vigor, and Euclidean distances.

\begin{tabular}{cccccc}
\hline \multirow{2}{*}{ Characterization } & \multicolumn{5}{c}{ Sweet corn seed lots } \\
\cline { 2 - 6 } & L-01 & L-02 & L-03 & L-04 & L-05 \\
\hline Germination (\%) & 84 & 87 & 90 & 83 & 86 \\
Cold test (\%) & 2 & 24 & 45 & 19 & 54 \\
Accelerated aging (\%) & 48 & 51 & 60 & 37 & 61 \\
Seedling dry matter (mg/pl) & 0.38 & 0.43 & 0.55 & 0.44 & 0.47 \\
Distance between lots* & L-01 & L-02 & L-03 & L-04 & L-05 \\
L-01 & 0.0 & - & - & - & - \\
L-02 & 1.8 & 0.0 & - & - & - \\
L-03 & 4.1 & 2.4 & 0.0 & - & - \\
L-04 & 1.8 & 2.3 & 4.1 & 0.0 & - \\
L-05 & 3.3 & 1.9 & 1.9 & 3.3 & 0.0 \\
\hline
\end{tabular}

* Euclidean distance 
With application of principal component analysis, a new component $\left(\mathrm{PC}_{1}\right)$ encompassed $77.9 \%$ of all data variability. This component consisted of greater weights for the results obtained in the germination (0.89), cold (0.89), accelerated aging (0.89), and total dry matter (0.86) tests. These results show that the greater the score of the lots for $\mathrm{PC}_{1}$, the greater seed physiological potential was. For its part, the second component $\left(\mathrm{PC}_{2}\right)$ represented $12.7 \%$ of the variability, and this component was constituted by the weight of accelerated aging $(-0.38)$. Thus, the lower the value of the lots for this component $\left(\mathrm{PC}_{2}\right)$, the greater the probability of seeds germinating after being subjected to the adverse conditions of the test.

Thus, L-05 and L-03 (similar lots according to clustering, Figure 1A) had greater scores of $\mathrm{CP}_{1}$ than the other lots, and they were classified as those that had higher vigorous seeds
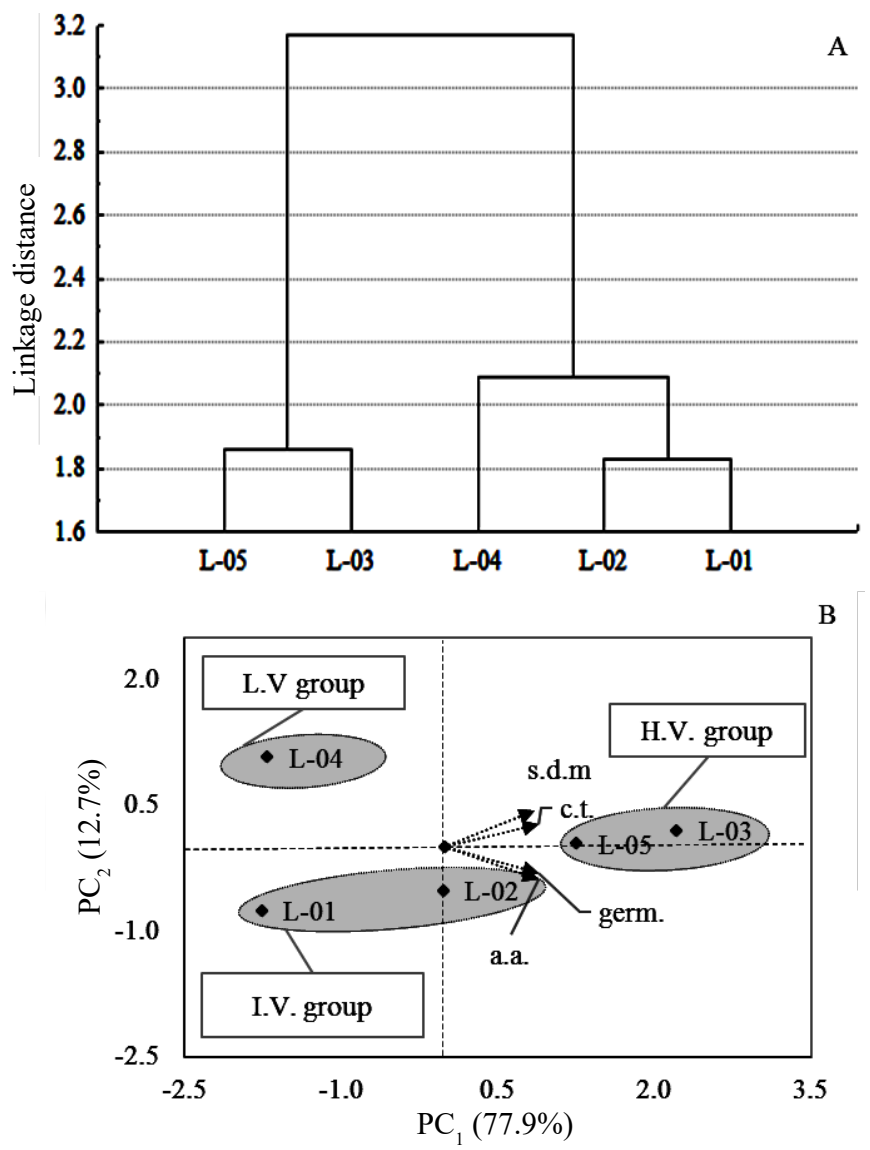

Figure 1. A) Supplemental dendrogram for characterization of sweet corn seed lots in regard to vigor. B) Visual representation of the principal components (biplot) with separation based on seeds higher vigor (H.V. group), intermediary vigor (I.V. group), and lower vigor (L.V. group) in accordance with cluster analysis. (germ $=$ germination; a.a. $=$ accelerated aging; c.t.= cold test; s.d.m. $=$ seedling dry mass).
(H.V. Group, Figure 1B). In contrast, L-01 and L-02 (similar lots according to clustering, Figure 1A) showed intermediate scores for this component and were classified as intermediary vigor seeds (I.V. Group, Figure 1B). Lot L-04 did not form any group of analysis, as shown in principal component analysis. It had the lowest score for $\mathrm{PC}_{1}$ and the highest for $\mathrm{PC}_{2}$. Therefore, it was classified as the lot that had the lowest vigor seeds (L.V. Group, Figure 1B).

From these classificatory results, one of the most vigorous seed lots (L-03) was selected randomized to contrast with the one of lowest vigor (L-04). With the lots selected, a seedling emergence test was set up in a greenhouse for confirmation of vigor levels.

Through the results obtained, the vigor difference between the lots was effectively confirmed, which had initially been determined by laboratory examinations (Figure 2). After confirmation of the vigor difference, the lots (L-03 and L-04) were subjected to the submersion test. The moisture content of the seeds increased considerably according to the increase in the submersion period, indicating progressive imbibition. The greatest gain in moisture content occurred in the first 24 hours for both lots (Table 2).

According to Cavariani et al. (2009), the rate of water uptake by the seed may be an indication of physiological

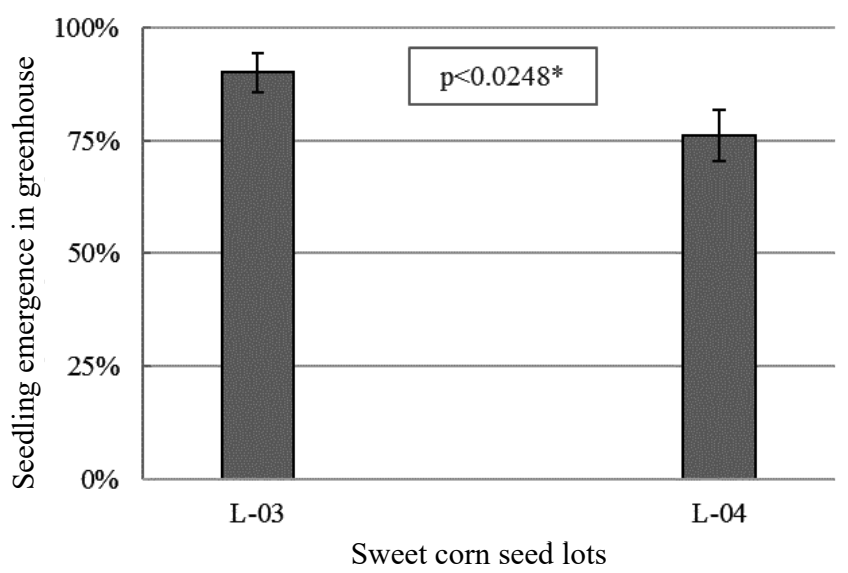

Figure 2. Seedling emergence under greenhouse conditions of the seed lots L-03 and L-04 of sweet corn.

Table 2. Progression of imbibition in \% moisture of sweet corn in high vigor (L-03) and low vigor (L-04) seed lots, Tropical Plus hybrid, Zea mays L.

\begin{tabular}{cccccc}
\hline \multirow{2}{*}{ Lots } & \multicolumn{5}{c}{ Seed submersion time } \\
\cline { 2 - 6 } & $0 \mathrm{~h}$ & $24 \mathrm{~h}$ & $48 \mathrm{~h}$ & $72 \mathrm{~h}$ & $96 \mathrm{~h}$ \\
\hline L-03 & $8.2 \pm 0.2$ & $54.1 \pm 0.6$ & $58.7 \pm 0.7$ & $60.0 \pm 0.3$ & $62.9 \pm 1.4$ \\
L-04 & $8.4 \pm 0.2$ & $56.9 \pm 0.7$ & $61.2 \pm 0.5$ & $62.4 \pm 0.5$ & $64.3 \pm 0.6$ \\
\hline
\end{tabular}


quality. Costa et al. (2002) found that soybean seeds of lower physiological quality exhibited greater rates of water uptake in the first hours of imbibition, which may be related to the integrity of the seed coat. Low quality seeds generally show damage in the seed coat or tissues, due to deterioration.

Grzybowski et al. (2015), studying the submersion test as a stress test for evaluation of common maize seed vigor, found greater gain in moisture content in the first 24 hours; the increase in moisture in the other periods was less, corroborating the results obtained in this study.

This occurs because the first phase of hydration only involves a physical process of diffusion, which is regulated by the cell water potential, always from greater (substrate) to lower (seed) potential, regardless of the viability of the seeds. This first phase is highly dependent on the permeability of the seed coat and of the colloids that constitute the seed, which in the case of sweet corn, facilitates water entry even more due to its intrinsic characteristics, such as lower thickness of the pericarp and the fragility of the membranes (Bewley et al., 2013; Zucareli et al., 2013).

In regard to seed performance, the percentages of primary root emission and of seed germination in sweet corn decreased as the period of submersion increased (Figures $3 \mathrm{~A}$ and $3 \mathrm{~B}$ ), with negative reflection for the final percentage of germination (Figure 3B). According to Marcos-Filho (2015), emergence of the primary root is not sufficient to evaluate if the seedling will continue to grow normally and, for that reason, the percentage of germination is generally lower than the percentage of seeds that develop a primary root. Normal and abnormal seedlings may have a primary root; however, only normal seedlings are counted in evaluation of germination.

Submersion was able to negatively affect seed germination, because as the periods in which the seeds are submerged increases, oxygen availability is reduced (Lima et al., 2004). According to Tang et al. (2014), oxygen levels are fundamental for germination of the species; levels below 6 and $2 \mathrm{kPa}$ are already enough to inhibit the process. Since oxygen gas is essential in aerobic respiration, lack of oxygen gas leads to lower efficiency in energy formation, which limits initial development of the seeds. In addition to energy availability, rapid entry of water into the seed might bring about imbibition damage, due to the large difference in water potential (Costa et al., 2008).

According to Vaz-de-Melo et al. (2012), under stress conditions caused by flooding and injury, as in damage by imbibition, seedlings direct their metabolism to get around these conditions. This results in greater energy spent for adaptation and reduces the energy available for germination, which ends up being negatively affected (Custódio et al., 2009). Dantas et al. (2000) observed that maize plants under periods of flooding greater than 24 hours exhibited a decrease of approximately $40 \%$ in normal seedlings at the time of first germination count, corroborating the results obtained here.

It is important to highlight that although they exhibited significant differences in regard to physiological potential and proved to be sensitive to a flooded condition, the sweet corn seed lots under the submersion test exhibited similar responses, indicating that it is not possible to discriminate them under the conditions of $25^{\circ} \mathrm{C}$ in the periods of $24,48,72$, and 96 hours.

Grzybowski et al. (2015) studied the submersion test as a stress test at different times and temperatures. In contrast with the results obtained above, they concluded that if performed at $25^{\circ} \mathrm{C}$ for 48 hours, this test is adequate for evaluation of maize seed vigor. The reason is that more vigorous seeds are more tolerant to oxygen deficiency and to the presence of pathogens favored by high moisture conditions (Dantas et al., 2000).

Nevertheless, for sweet corn, the periods of submersion may have been quite drastic, due to the greater fragility of these seeds to conditions of excess water. This, together with the highly reduced water potential of the seeds, led to
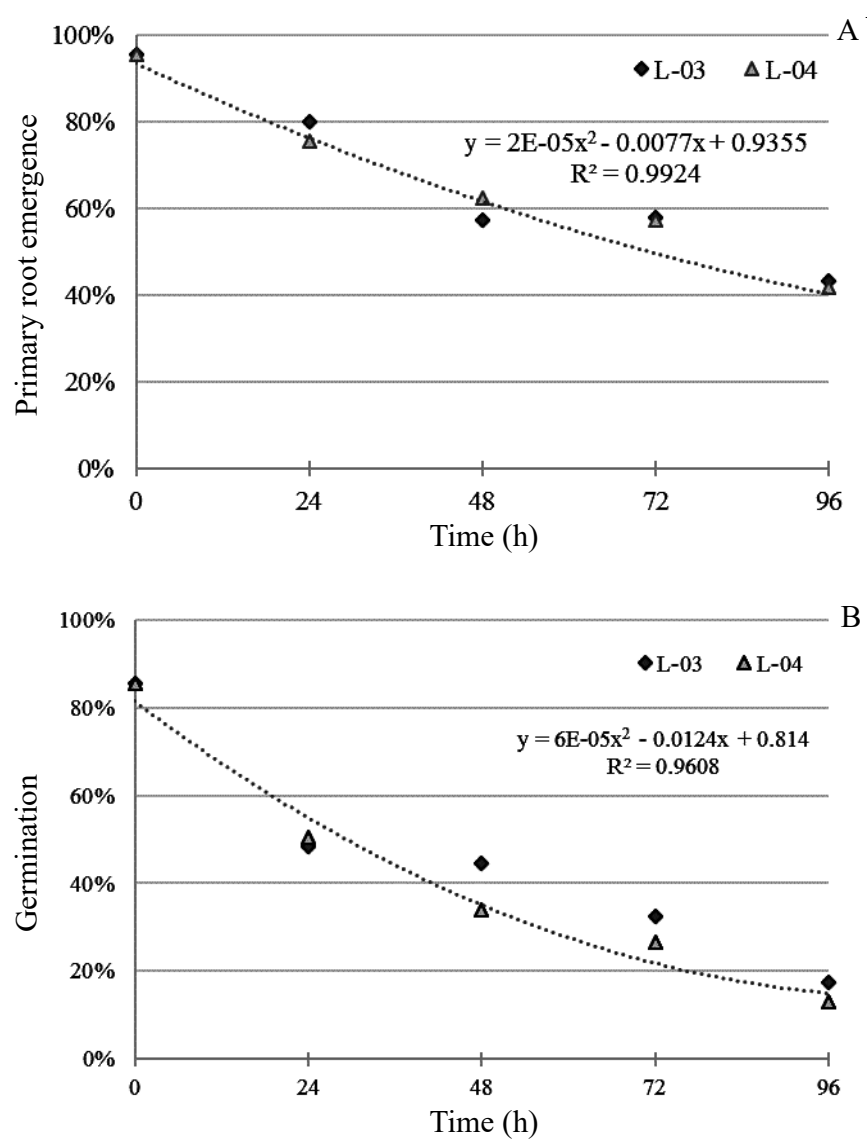

Figure 3. Percentage of primary root emergence (A) and percentage of germination (B) of sweet corn seeds under different periods of submersion. 
accelerated imbibition. Accelerated imbibition, for its part, may have caused rupture of tissues and disorganization of membranes, bringing about irreversible losses. (Zucareli et al., 2008). In addition, Silva and Carvalho (2008), studying Clitoria fairchildiana seedlings reported that excess of water in imbibition reduces germination, which may be related to the increase in anaerobic respiration that leads to tissue death through production of toxic substances, even in vigorous seeds.

\section{Conclusions}

Discrimination of sweet corn seed lots is possible by means of application of multivariate analysis, exhibiting consistency of seedling emergence with seed lots of contrasting physiological characteristics.

Sweet corn is sensitive to submersion in water, with progressive reduction of primary root emergence and of germination from 24 hours on. However, the test is not efficient in classification of sweet corn seed lots in regard to vigor.

\section{References}

ALVARENGA, R.O.; MARCOS-FILHO, J.; TIMÓTEO, T.S. Assessment of the physiological potential of super sweet corn seeds. Journal of Seed Science, v.35, n.3, p.340-346, 2013. http:// dx.doi.org/10.1590/S2317-15372013000300010

AOSA. Association of Official Seed Analysts. Seed Vigor Testing Handbook. Lincoln, 2009. 105p.

BEWLEY, J.D.; BRADFORD, K.J.; HILHORST, H.W.M.; NONOGAKI, H. Seeds: Physiology of Development, Germination and Dormancy, 3. ed. Nova York: Springer, 2013. 392p.

BRASIL. Ministério da Agricultura, Pecuária e Abastecimento. Regras para análise de sementes. Ministério da Agricultura, Pecuária e Abastecimento. Secretaria de Defesa Agropecuária. Brasília: MAPA/ACS, 2009. 395p.

BRASIL. Ministério da Agricultura, Pecuária e Abastecimento. Instrução Normativa $N^{\circ} 45$ de 2013. Brasília, DF: MAPA/ DAS/CSM, 2013. 38p. http://www.abrasem.com.br/wp-content/ uploads $/ 2012 / 10 /$ Instru $\%$ C 3\%A 7\%C3\%A3o-Normativan\%C2\%BA-45-de-17-de-Setembro-de-2013-Padr\%C3\%B5es-deIdentidade-e-Qualiidade-Prod-e-Comerc-de-Sementes-GrandesCulturas-Republica\%C3\%A7\%C3\%A3o-DOU-20.09.13.pdf

CAVARIANI, C.; TOLEDO, M.Z.; RODELLA, R.A.; FRANÇANETO, J.B.; NAKAGAWA, J. Velocidade de hidratação em função de características do tegumento de sementes de soja de diferentes cultivares e localidades. Revista Brasileira de Sementes, v.31, n.1, p.031-039, 2009. http://dx.doi.org/10.1590/S0101-31222009000100004.

CÍCERO, S.M.; VIEIRA, R.D. Teste de frio. In: VIEIRA, R.D.; CARVALHO, N.M. (Ed.). Testes de Vigor em Sementes. Jaboticabal: FUNEP/UNESP, 1994. p.151-164.
COSTA, J.A.; PIRES, J.L.F.; THOMAS, A.L.; ALBERTON, M. Variedades de soja diferem na velocidade e capacidade de absorver água. Scientia Agraria, v.3, n.1, p.91-96, 2002. http://dx.doi. org/10.5380/rsa.v3i1.1036.

COSTA, C.J.; VILLELA, F.A.; BERTONCELLO, M.R.; TILLMANN, M.A.A.; MENEZES, N.L. Pré-hidratação de sementes de ervilha e sua interferência na avaliação do potencial fisiológico. Revista Brasileira de Sementes, v.30, n.1, p.198-207, 2008. http://dx.doi.org/10.1590/ S0101-31222008000100025.

CUSTÓDIO, C.C.; MACHADO NETO, N.B.; MORENO, E.L.C.; VUOLO, B.G. Water submersion of bean seeds in the vigour evaluation. Revista Brasileira de Ciências Agrárias, v.4, n.3, p.261266, 2009. http://www.redalyc.org/articulo.oa?id=119012585005

DANTAS, B.F.; ARAGÃO, C.A.; CAVARIANI, C.; NAKAGAWA, J. Teste de alagamento para avaliação do vigor em sementes de milho. Revista Brasileira de Sementes, v.22, n.2, p.288-292, 2000. http://dx.doi.org/10.17801/0101-3122/rbs.v22n2p288-292

FORTES, F.O.; LÚCIO, A.D.C.; LOPES, S.J.; CARPES, R.H.; SILVEIRA, B.D. Agrupamento em amostras de sementes de espécies florestais nativas do Estado do Rio Grande do Sul - Brasil. Ciência Rural, v.38, n.6, p.1615-1623, 2008. http://www.scielo.br/pdf/cr/ v38n6/a19v38n6.pdf

GRZYBOWSKI, C.R.S.; VIEIRA, R.D.; PANOBIANCO, M. Testes de estresse na avaliação do vigor de sementes de milho. Revista Ciência Agronômica, v.46, n.3, p.590-596, 2015. http://www.scielo. $\mathrm{br} / \mathrm{pdf} / \mathrm{rca} / \mathrm{v} 46 \mathrm{n} 3 / 0045-6888-\mathrm{rca}-46-03-0590 . p d f$

LIMA, S.M.P.; GUIMARÃES, R.M.; OLIVEIRA, J.A.; VIEIRA, M.G.G.C. Efeitos de tempos e temperaturas de condicionamento sobre a qualidade fisiológica de sementes de cafeeiro (Coffea arábica L.) sob condições ideais de estresse térmico. Ciência Agrotécnica, v.28, n.3, p.505-514, 2004. http://dx.doi.org/10.1590/ S1413-70542004000300004.

LORENTZ, L.H.; NUNES, U.R. Relação entre medidas de qualidade de lotes de sementes de arroz. Revista Ciência Agronômica, v.44, n.4, p.798-804, 2013. http://ccarevista.ufc.br/seer/index.php/ccarevista/ article/view/2258/863

LUZ, J.M.Q.; CAMILO, J.S.; BARBIERI, V.H.B.; RANGEL, R.M.; OLIVEIRA, R.C. Produtividade de genótipos de milho doce e milho verde em função de intervalos de colheita. Horticultura Brasileira, v.32, n.2, p.163-167, 2014. http://dx.doi.org/10.1590/S010205362014000200007 .

MARCOS-FILHO, J. Fisiologia de sementes de plantas cultivadas. 2. Ed. Londrina, PR: ABRATES, 2015. 660p.

NAKAGAWA, J. Testes de vigor baseados no desempenho das plântulas. In: KRZYZANOWSKI, F.C.; FRANÇA-NETO, J.B.; VIEIRA, D.V. (Ed.). Vigor de sementes: conceitos e testes. Londrina: ABRATES, 1999. p.2.1-2.24.

SILVA, B.M.S.; CARVALHO, N.M. Efeitos do estresse hídrico sobre o desempenho germinativo da semente de faveira (Clitoria fairchildiana R.A. Howard. - FABACEAE) de diferentes tamanhos. Revista Brasileira de Sementes, v.30, n.1, p.55-65, 2008. http:// dx.doi.org/10.1590/S0101-31222008000100008. 
SOUZA, R.S.; VIDIGAL FILHO, P.S.; SCAPIM, C.A.; MARQUES, O.J.; QUEIROZ, D.C.; OKUMURA, R.S.; RECHE, D.L.; CORTINOVE, R.S. Produtividade e qualidade do milho doce em diferentes populações de plantas. Semina: Ciências Agrárias, v.34, n.3, p.995-1010, 2013. http://dx.doi.org/10.5433/16790359.2013v34n3p995-1010.

TANG; Y.; GAO, F.; GUO, S.; LI, F. Effects of hypobaria and hypoxia on seed germination of six plant species. Life Sciences in Space Research, v.3, p.24-31, 2014. https://doi.org/10.1016/j. lssr.2014.08.001

VAZ-DE-MELO, A.; SANTOS, L.D.T.; FINOTO, E.L.; DIAS, D.C.F.S.; ALVARENGA, E.N. Germinação e vigor de sementes de milho-pipoca submetidas ao estresse térmico e hídrico. Bioscience Journal, v.28, n.5, p.687-695, 2012. http://www.seer.ufu.br/index. $\mathrm{php} /$ biosciencejournal/article/view/11669

WILSON JUNIOR, D.O.; MOHAN, S.K. Unique seed quality problems of sh2 sweet corn. Seed Technology, v.20, n.2, p.176-186, 1998. http://agris.fao.org/agris-search/search.do;jsessionid=C214790CB7C06E8404F9D82A8FC78522?request_locale=es\&recordID=US $1999010115 \&$ source $Q u e r y=\&$ query $=\&$ sort Field $=\&$ sortOrder $=\&$ agrovocString $=\&$ advQuery $=\&$ centerString $=\&$ enableField
ZHAO, G.W.; SUN, Q.; WANG, J.H. Improving seed vigour assessment of super sweet and sugar-enhanced sweet corn (Zea mays saccharata). New Zealand Journal of Crop and Horticultural Science, v.35, p.349-356, 2007. http://dx.doi. org/10.1080/01140670709510201.

ZUCARELI, C.; CAVARIANI, C.; PORTUGAL, G.; NAKAGAWA, J. Potencial fisiológico de sementes de milho hidratadas pelo método do substrato de papel toalha. Revista Brasileira de Sementes, v.30, n.3, p.122-129, 2008. http://dx.doi.org/10.1590/S010131222008000300016 .

ZUCARELI, C.; BRZEZINSKI, C.R.; ABATI, J.; HENNING, F.A.; RAMOS JUNIOR, E.U.; NAKAGAWA, J. Lixiviação de íons potássio, cálcio e magnésio para determinação do vigor em sementes de milho doce. Informativo ABRATES, v.23, n.3, p.56-60, 2013. https://ainfo.cnptia.embrapa.br/digital/bitstream/item/98139/1/ Lixiviacao-de-ions-potassio-calcio-e-magnesio-para-determinacaodo-vigor-em-sementes-de-milho-doce.pdf 